\title{
Alluvial plain dynamics in the southern Amazonian foreland basin
}

\author{
Umberto Lombardo \\ CaSEs Research Group - UPF, Barcelona, Spain \\ Correspondence to: Umberto Lombardo (umberto.lombardo@upf.edu)
}

Received: 3 August 2015 - Published in Earth Syst. Dynam. Discuss.: 20 October 2015

Accepted: 19 April 2016 - Published: 10 May 2016

\begin{abstract}
Alluvial plains are formed with sediments that rivers deposit on the adjacent flood-basin, mainly through crevasse splays and avulsions. These result from a combination of processes, some of which push the river towards the crevasse threshold, while others act as triggers. Based on the floodplain sedimentation patterns of large rivers in the southern Amazonian foreland basin, it has been suggested that alluvial plain sediment accumulation is primarily the result of river crevasse splays and sheet sands triggered by above-normal precipitation events due to La Niña. However, more than $90 \%$ of the Amazonian river network is made of small rivers and it is unknown whether small river floodplain sedimentation is influenced by the ENSO cycle as well. Using Landsat images from 1984 to 2014, here I analyse the behaviour of all 12 tributaries of the Río Mamoré with a catchment in the Andes. I show that these are very active rivers and that the frequency of crevasses is not linked to ENSO activity. The data suggest that most of the sediments eroded from the Andes by the tributaries of the Mamore are deposited in the alluvial plains, before reaching the parent river. The mid-to-late Holocene paleo-channels of these rivers are located tens of kilometres further away from the Andes than the modern crevasses. I conclude that the frequency of crevasses is controlled by intrabasinal processes that act on a yearly to decadal timescale, while the average location of the crevasses is controlled by climatic or neo-tectonic events that act on a millennial scale. Finally, I discuss the implications of river dynamics on rural livelihoods and biodiversity in the Llanos de Moxos, a seasonally flooded savannah covering most of the southern Amazonian foreland basin and the world's largest RAMSAR site.
\end{abstract}

\section{Introduction}

Alluvial plains along the Andean foreland represent a large part of the South American wetlands and seasonally flooded landscapes and provide important ecological services (Melack and Hess, 2011; Junk, 2013). These landscapes are characterized by fragile hydrological systems, increasingly threatened by climate change and human activity (Junk, 2013). These alluvial plains are built with the sediments that rivers bring from the eastern flank of the Andes and deposit on the Andean foreland basin. River activity is continuously reshaping the landscape, with far reaching implications for rural populations and biodiversity. Through meandering, the formation of crevasse splays, avulsions and backswamp sedimentation, rivers fill sedimentary basins (Slingerland and Smith, 2004); they create an irregular topography, favouring the formation of diverse ecological niches (Lewin and Ashworth, 2014); they generate the flood pulses that maintain the biota in river-floodplain systems (Junk et al., 1989); and they cause disturbance in forest structure, which, in turn, is key in creating and maintaining biodiversity (Salo et al., 1986; Nelson et al., 1994). River activity can cause important economic losses (Latrubesse et al., 2009b; Marengo et al., 2013) and greatly affect the livelihoods of rural communities, particularly indigenous people who are often settled along these rivers and depend on their resources (Pärssinen et al., 1996). Understanding what controls fluvial processes in the Andean foreland basin and how these rivers react to external forcing is fundamental in order to foresee how floodplains and alluvial plains will respond to future pressures (Thompson et al., 2013). 
In the last few decades, an increasing number of studies in the Andean-Amazonian foreland basin have furthered our knowledge of river dynamics and floodplain erosion/sedimentation processes and forest disturbance (do Nascimento Jr. et al., 2015; Dunne et al., 1998; Salo et al., 1986; Peixoto et al., 2009; Constantine et al., 2014; Aalto et al., 2003; Latrubesse et al., 2009a; Wittmann et al., 2009). In the southern Amazonian foreland basin (SAFB) (Espurt et al., 2007) it has been shown that large river floodplain sediment accumulation observed in $\sim 100$ dated floodplain cores is primarily controlled by the El Niño/Southern Oscillation (ENSO) cycle (Aalto et al., 2003), with warm (El Niño) phases causing smaller shorter floods and low sedimentation rates and cold (La Niña) phases causing larger longer floods and high sedimentation rates (Aalto et al., 2003; Schöngart and Junk, 2007).

However, most of these studies have focused on the Amazon River's main tributaries, Strahler stream order higher than 7 , overlooking the contribution of lower order tributaries, which account for more than $90 \%$ of the total length of the Amazonian river network (Mayorga et al., 2005). Conclusions drawn from these studies of large Amazon rivers cannot be extrapolated to small rivers, because they differ in important aspects (Ashworth and Lewin, 2012). In the SAFB, the patterns of paleo channels show that it is not the large Río Mamoré but rather its tributaries that have deposited most of the sediments that form the modern alluvial plains (Lombardo et al., 2012; Lombardo, 2014; Hanagarth, 1993). Hence, it is important to further our understanding of the behaviour of these tributaries and the mechanisms controlling alluvial plain sediment accumulation.

Thanks to the availability of Landsat imagery with subannual temporal resolution covering the last 3 decades, it is now possible to document river spatial and temporal changes and make inferences regarding large-scale changes in hydrology, sedimentation patterns and river sedimentary loads (Buehler et al., 2011; Peixoto et al., 2009; Constantine et al., 2014). Here, I use several time series of LANDSAT images from 1984 to 2014 to analyse the behaviour of the 12 tributaries of the Río Mamore which have their headwaters in the Andes: the Maniqui, Sécure, Moleto, Isiboro, Chipiriri, Chapare, Chimoré, Sacta, Ichilo, Yapacaní, Piraí and Grande (Fig. 1). The geomorphology of these rivers has never been studied before and hydrological and geochemical data only exist for four of them: the Grande, the Piraí, the Yapacaní and the Ichilo rivers (Guyot et al., 1994, 2007). In this paper I analyse the occurrence of crevasses, a breach in the river levee, and river avulsions, the abrupt abandonment of a channel for a new course at a lower elevation (Slingerland and Smith, 1998, 2004) and the link between these processes and strong to extreme ENSO events. I investigate how these rivers contribute to the formation of the alluvial plain and affect the local forest-savannah ecotone and forest disturbance. Although the analysis of optical remote-sensing imagery here presented does not provide quantitative data on sedimentary processes, it does allow a qualitative assessment of these processes and a re-interpretation of existing quantitative data. The impact of river dynamics on indigenous communities and the rural economy is also explored, with particular emphasis on how these highly active rivers may affect the viability of the planned highway across the National Park Territorio Indígena y Parque Nacional Isiboro Secure (TIPNIS) in Bolivia.

\section{Study area}

The SAFB is a largely pristine environment, where rivers move freely across the alluvial plains. The SAFB is drained by three large rivers: the Beni, the Mamoré and the Iténez (o Guaporé). It comprises two regions, the seasonally flooded savannah of the Llanos de Moxos (LM), where nine out of the 12 tributaries of the Mamoré are located, and the northern part of the Department of Santa Cruz, where the remaining three rivers are located (Fig. 1). These rivers drain the Andean catchment of the Mamoré, which includes the second most important rainfall hotspot of the southern tropical Andes (Espinoza et al., 2015). Several paleocourses of the Río Beni have been identified, these seem to be the result of avulsions caused by a fault located a few kilometers from the Andes (Dumont and Fournier, 1994). The Mamoré avulsed during the mid-to-late Holocene (Plotzki et al., 2013) and occupied one of the Río Beni paleocurses (Lombardo, 2014). Stratigraphic cores performed across the alluvial plain have shown that, since the mid-Holocene, distributary fluvial systems formed by the Mamoré's tributaries (Fig. 1) have deposited thick layers of sediments over the southern and central part of the LM (Lombardo, 2014; Plotzki et al., 2015). This region hosts one of the most important collections of pre-Columbian earthworks in Amazonia, including monumental mounds, raised fields, ring ditches, fish weirs, canals and causeways (Lombardo et al., 2011; Prümers and Jaimes Betancourt, 2014). Throughout the Holocene, river avulsions have played a central role in both causing the abandonment and burial of early Holocene archaeological sites (Lombardo et al., 2013) and later favouring the development of pre-Columbian complex societies through the deposition of fertile and relatively well drained sediments (Lombardo et al., 2015, 2012). The LM is largely covered by savannahs, crisscrossed by strips and patches of forest that grow on slightly elevated fluvial deposits, mostly river levees and crevasse splays. This forest-savannah patchwork is key for the survival of its rich biodiversity, which includes several endemic, rare and threatened species (Herzog et al., 2012; Wallace et al., 2013; Langstroth, 2011). The recent designation of three new protected areas in the LM has made it the world's largest Ramsar site, which is a protection scheme for wetlands of worldwide ecological importance (http://www.worldwildlife.org/press-releases/ last access: 15 March 2016). The LM constitutes the southern bor- 


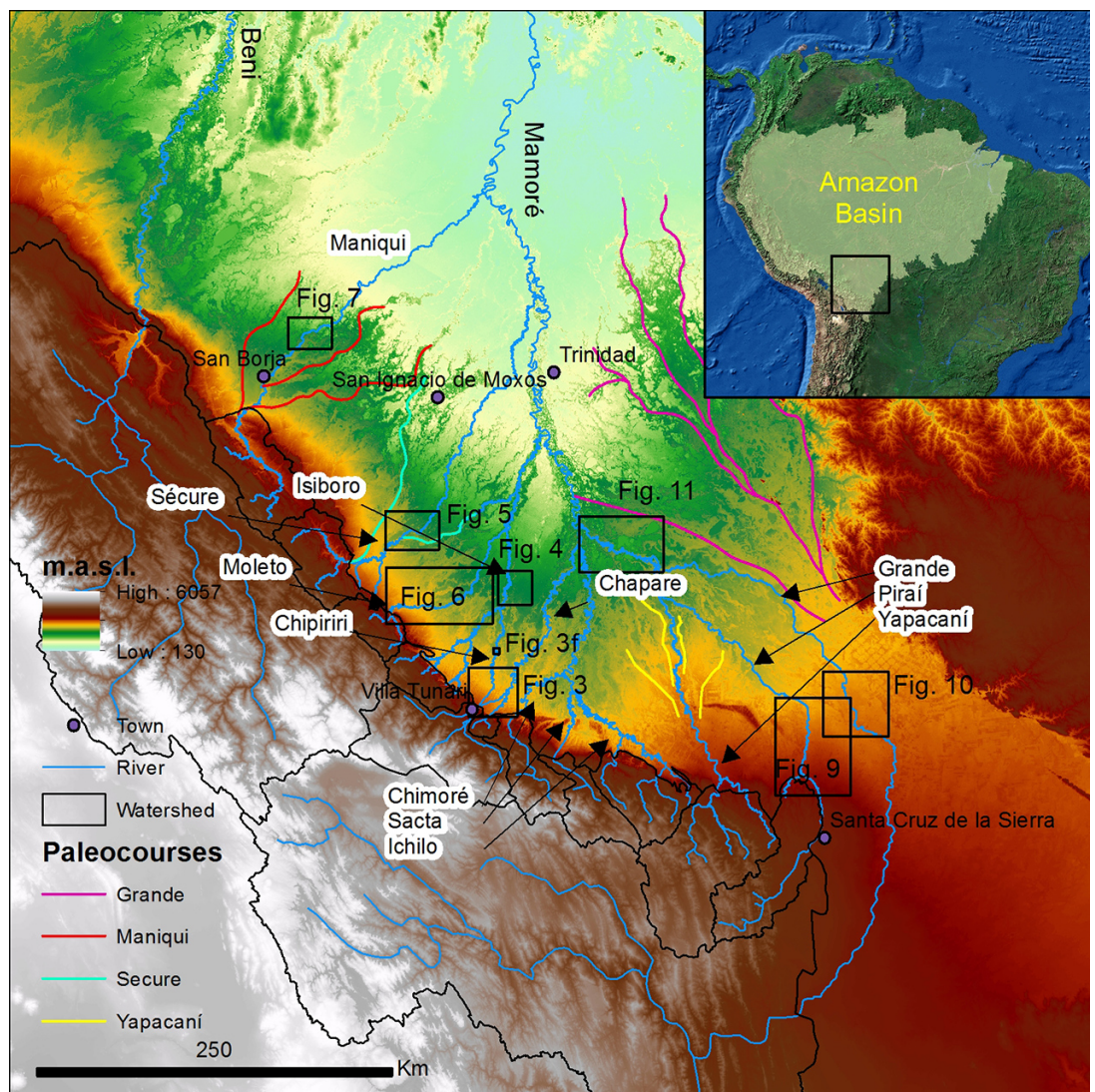

Figure 1. The southern Amazonian foreland basin (SAFB) and the Río Mamoré network. The rivers studied include all the tributaries of the Río Mamoré that have part of their catchment in the Andes. Out of the 12 rivers studied, nine are located in the seasonally flooded savannah of the Llanos de Moxos: the Maniqui, Sécure, Moleto, Isiboro, Chipiriri, Chapare, Chimoré, Sacta and the Ichilo. The remaining three, the Grande, the Piraí and the Yapacaní, flow mostly within the Department of Santa Cruz. The Mamoré, together with the Río Beni, provide most of the sediments and water to the Río Madeira, which is the largest tributary of the Amazon River. The Río Beni drains about $70000 \mathrm{~km}^{2}$ of the Andes. The 12 tributaries of the Mamoré drain more than $93000 \mathrm{~km}^{2}$. Elevation colours are rendered applying histogram equalize stretch.

der of the Amazonian rainforest, hence a preferential area to study forest-savannah dynamics (Carson et al., 2014; Mayle et al., 2000; Whitney et al., 2011).

\section{Methods}

All 12 tributaries of the Río Mamoré with a catchment in the Andes have been included in this study. Crevasse splays and avulsions since 1984 have been identified using the Landsat Annual timelapse in Google Earth Engine (https: //earthengine.google.org/\#intro/Amazon). Subsets of Landsat imagery have been downloaded from the USGS service LandsatLook (http://landsatlook.usgs.gov/viewer.html), these include all the river reaches identified for all the years where high-quality coverage is available (Table 1). Images have been transformed into 2 bit (black and white) data sets and channel centrelines have been digitalized using the ArcScan extension of ArcGis software. Meander migration rates have been calculated as in Micheli et al. (2004) and Con- stantine et al. (2014). Values of the Multivariate ENSO Index (MEI) (Wolter and Timlin, 2011) have been downloaded from http://www.esrl.noaa.gov/psd/enso/mei/rank.html. As in Aalto et al. (2003), only the ranks of the early rainy season months for Bolivia have been included in the analysis.

\section{Results and interpretation}

During the 30-year period for which images are available, the Mamoré's tributaries show extremely high activity: 41 crevasses opened up along seven of the 12 tributaries, 29 of which initiated an avulsion process (Table 2,3 ). Only 8 out of the 41 crevasses for which the exact year of formation has been identified coincide with La Niña years, while 12 coincide with El Niño years and 21 crevasses opened up in years of no moderate to strong ENSO activity (Table 4). No crevasses initiated during El Niño years 1987, 1992, 1998 and 2003 or during La Niña in 1989 and 1999. Except for the Río Grande, crevasses are found at an average distance 
Table 1. Years for which images were not downloaded from the USGS service LandsatLook. Images taken in the years within the 1984-2014 range not listed in the second column have been downloaded and used.

\begin{tabular}{llll}
\hline River & Years with no quality imagery available within the 1984-2014 range & Start point & End point \\
\hline Maniqui & 2012 & $-66.91 /-15.18$ & $-65.67 /-14.00$ \\
Secure & $1987,1992,1993,1998,2000,2007,2008,2012$ & $-66-17 /-16.0$ & $-65.50 /-15.69$ \\
Moleto & $1986,1988,1997,2002,2004,2008,2012$ & $-65.93 /-16.36$ & $-65.36 /-16.07$ \\
Isiboro & 2008,2012 & $-65.44 /-16.53$ & $-65.08 /-15.95$ \\
Chipiriri & 1986,2012 & $-65.29 /-16.78$ & $-65.23 /-16.30$ \\
Chapare & $1984,1985,1987,1992,1994,2000,2001,2003,2005,2006,2007,2008,2012$ & $-65.23 /-16.94$ & $-64.99 /-16.56$ \\
Chimoré & $1984,1985,1987,1992,1994,2000,2001,2003,2005,2006,2007,2008,2012$ & $-65.09 /-16.98$ & $-64.83 /-16.76$ \\
Sacta & $1984,1985,1987,1992,1994,2000,2001,2003,2005,2006,2007,2008,2012$ & $-64.81 /-17.11$ & $-64.78 /-16.85$ \\
Ichilo & $1984,1985,1987,1992,1994,2000,2001,2003,2005,2006,2007,2008,2012$ & $-64.59 /-17.05$ & $-64.79 /-16.85$ \\
Yapacaní & $1985,1987,1989,1995,2002,2004,2008,2012,2013$ & $-64.11 /-16.59$ & $-64.53 /-15.97$ \\
Piraí & $1985,1986,1989,1991,1992,1997,1999,2006,20072008,2012$ & $-63.21 /-17.54$ & $-63.84 /-16.50$ \\
Grande & $1985,1986,2003,2004,2011,2012$ & $-62.72 /-17.25$ & $-63.40 /-16.54$ \\
\hline
\end{tabular}

of $68 \mathrm{~km}(\sigma 23)$ from the point in which the rivers enter the alluvial plains. In the case of the Río Grande this distance is $276 \mathrm{~km}(\sigma 63.4)$. All the modern crevasses are closer to the Andes than the mid- to late Holocene terminal splays of the distributary systems formed by these rivers (Fig. 1), particularly in the case of the Río Grande, which during the mid- to late Holocene deposited a sedimentary lobe $280 \mathrm{~km}$ further away from the Andes (Lombardo et al., 2012).

Based on their behaviour (Table 3), the tributaries of the Mamoré can be grouped into three categories (Fig. 2): rivers that do not show evidence of avulsions in the last 30 years, with a multi-thread channel along the piedmont that becomes a single-thread meandering channel once it enters the alluvial plains (Chipiriri, Chapare, Chimoré, Ichilo, Sacta); rivers avulsing on a multi-decadal timescale (Sécure, Isiboro, Moleto, Yapacaní); and rivers avulsing on a sub-decadal timescale (Maniqui, Piraí, Grande).

\subsection{Rivers with low avulsion rates}

These rivers have high sinuosity and high meandering migration rates and show very little or no evidence of crevasse splays in the last 30 years (Table 3). They bring most of their total suspended sediments (TSS) to the Mamoré. In the case of the Chimoré, Ichilo and Sacta rivers, there seems to have been no change in the amount of sediments brought to the Mamoré since the 1980s. However, important changes in the sediment load of the Chapare and Chipiriri can be detected. The Chapare and the Chipiriri, a tributary of the Isiboro, fan out from a common catchment. This catchment, although relatively small, includes the second most important rainfall hotspot of the southern tropical Andes (Espinoza et al., 2015), where precipitation easily reaches $5000 \mathrm{~mm} \mathrm{yr}^{-1}$. Since 1984, the Chipiriri has been gradually taking over a larger share of the total basin discharge at Villa Tunari, the fan apex, at the expense of the Chapare (Fig. 3). The switch of water flow from Chapare to Chipiriri became important

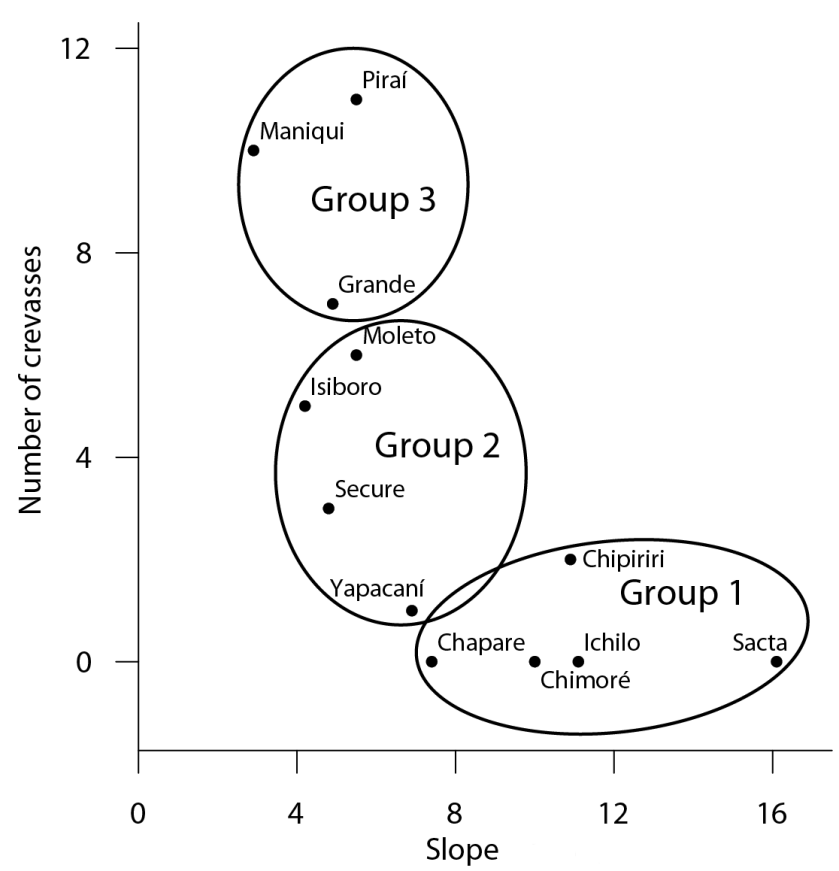

Figure 2. Number of crevasses detected since 1984 plotted against average river slope (see Table 3). Crevasses open up when the slope falls below 7.5 (0.00075).

after 1998, as it can be observed by the increase in the meandering of the Chipiriri (Fig. 3f). A similar process was described in the piedmont of the Chaco basin, where stream captures can change the size of a given river's drainage basin (Baker, 1977). The width of the Chipiriri is about one third of the Chapare in 1986 (Fig. 3a), but by 2014 the Chipiriri is far wider than the Chapare (Fig. 3e). Between 1984 and 2014 two crevasses opened up in the Chipiriri, at 61 and $65 \mathrm{~km}$ downstream from Villa Tunari; none of these crevasses led to avulsions. 
Table 2. Tributaries of the Río Mamoré: crevasse splays and avulsion events since 1984. Dates refer to the day in which the image used to identify crevasses and avulsions was taken; Start year is the year in which the crevasse is first identified; End year is the year in which the avulsion is completed, when the totality of the river flow is diverted into a new channel; Distance is the down-valley distance of the crevasse from the point where the river enters the alluvial plain, expressed in kilometre. No data in End year indicates that the crevasse did not develop into an avulsion.

\begin{tabular}{|c|c|c|c|c|}
\hline River & Dates & Start year & End year & $\begin{array}{l}\text { Distance } \\
(\mathrm{km})\end{array}$ \\
\hline Chipiriri & $14 / 04 / 1993$ & 1993 & - & 65 \\
\hline Chipiriri & 07/08/1994 & 1994 & - & 61 \\
\hline Grande & $11 / 01 / 1985$ & 1985 & - & 270 \\
\hline Grande & $26 / 06 / 1993$ & 1993 & 1994 & 243 \\
\hline Grande & $16 / 06 / 1995$ & 1995 & 1995 & 240 \\
\hline Grande & $12 / 06 / 2001$ & 2001 & 2001 & 250 \\
\hline Grande & $24 / 08 / 2002$ & 2002 & 2002 & 250 \\
\hline Grande & $17 / 08 / 1997$ & 1997 & in progress & 430 \\
\hline Grande & $23 / 09 / 2008$ & 2008 & 2008 & 251 \\
\hline Isiboro & 07/08/1994 & 1994 & 1996 & 74 \\
\hline Isiboro & $24 / 10 / 2008$ & 2008 & - & 79 \\
\hline Isiboro & 03/10/2009 & 2009 & - & 78 \\
\hline Isiboro & $16 / 08 / 2012$ & 2012 & 2012 & 87 \\
\hline Isiboro & $11 / 08 / 1984$ & $<1984$ & in progress & 71 \\
\hline Maniqui & $10 / 11 / 1997$ & 1997 & 1999 & 95 \\
\hline Maniqui & $25 / 08 / 2001$ & 2001 & 2001 & 90 \\
\hline Maniqui & $25 / 02 / 2002$ & 2002 & 2002 & 89 \\
\hline Maniqui & $31 / 08 / 2006$ & 2006 & 2006 & 81 \\
\hline Maniqui & 03/09/2007 & 2007 & - & 79 \\
\hline Maniqui & $20 / 08 / 2008$ & 2008 & 2011 & 79 \\
\hline Maniqui & $02 / 08 / 2013$ & 2013 & - & 75 \\
\hline Maniqui & $22 / 09 / 2014$ & 2014 & 2014 & 71 \\
\hline Maniqui & 05/10/1984 & $<1984$ & 1993 & 96 \\
\hline Maniqui & 05/10/1984 & $<1984$ & - & 70 \\
\hline Moleto & $12 / 02 / 1988$ & 1988 & 1988 & 65 \\
\hline Moleto & $12 / 06 / 2000$ & 2000 & 2001 & 15 \\
\hline Moleto & $08 / 01 / 2002$ & 2002 & - & 9 \\
\hline Moleto & $16 / 06 / 2010$ & 2010 & - & 42 \\
\hline Moleto & 06/08/2011 & 2011 & - & 40 \\
\hline Moleto & 03/07/2012 & 2012 & 2013 & 38 \\
\hline Piraí & $11 / 09 / 1986$ & 1986 & 1986 & 98 \\
\hline Piraí & 09/04/1988 & 1988 & 1989 & 54 \\
\hline Piraí & 05/08/1990 & 1990 & 1990 & 106 \\
\hline Piraí & $26 / 02 / 1990$ & 1990 & 1990 & 73 \\
\hline Piraí & $18 / 02 / 1993$ & 1993 & 1993 & 54 \\
\hline Piraí & 29/06/1994 & 1994 & 1994 & 54 \\
\hline Piraí & $27 / 04 / 2006$ & 2006 & - & 57 \\
\hline Piraí & $14 / 04 / 2007$ & 2007 & - & 53 \\
\hline Piraí & $23 / 09 / 2008$ & 2008 & 2008 & 113 \\
\hline Piraí & $06 / 04 / 2010$ & 2010 & 2010 & 113 \\
\hline Piraí & $06 / 04 / 2010$ & 2010 & 2010 & 63 \\
\hline Sécure & $13 / 02 / 1986$ & 1986 & 2006 & 45 \\
\hline Sécure & $23 / 09 / 1997$ & 1997 & 1997 & 47 \\
\hline Sécure & $07 / 06 / 2010$ & 2010 & 2010 & 54 \\
\hline Yapacaní & $30 / 04 / 1984$ & $<1984$ & 1994 & 160 \\
\hline
\end{tabular}

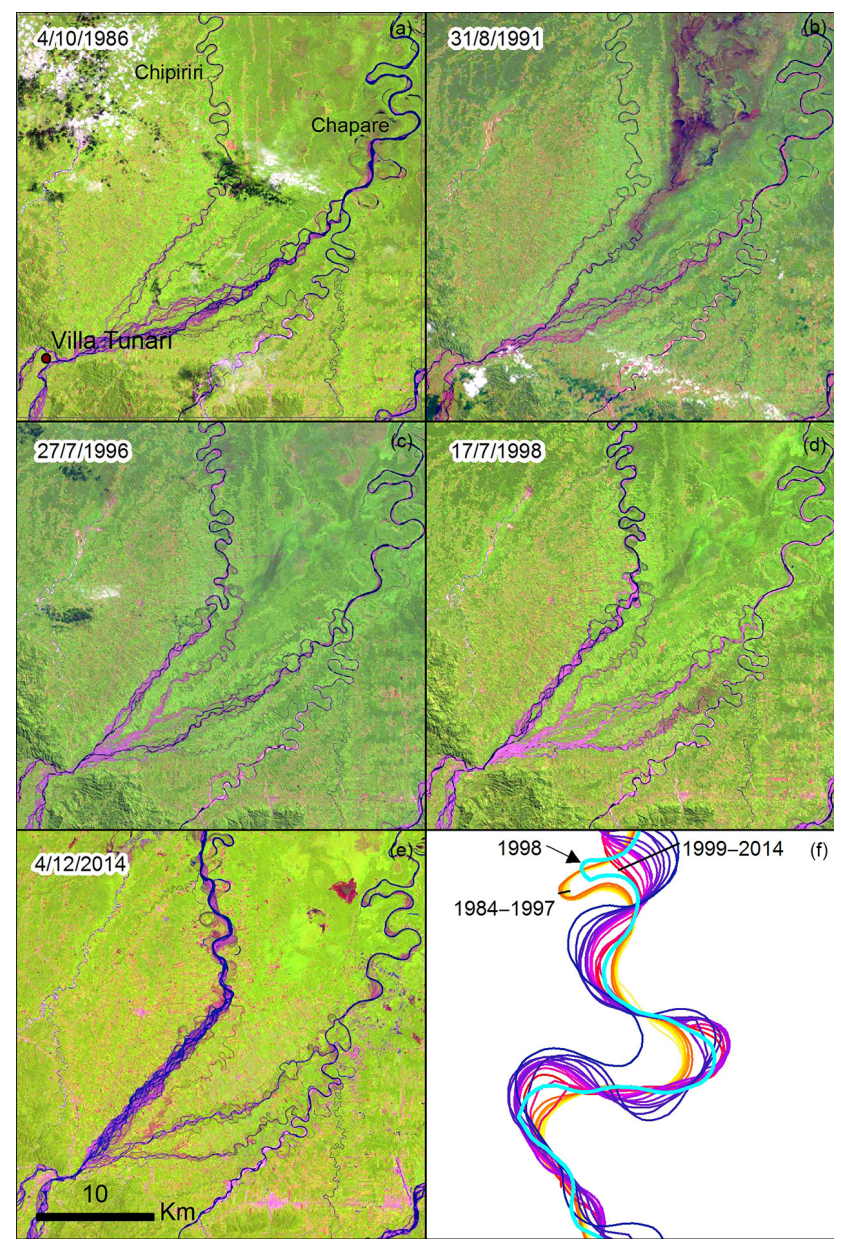

Figure 3. Río Chipiriri and río Chapare. From the fan apex in Villa Tunari, several braided courses converge to form the Chipiriri and the Chapare rivers. Landsat images taken at different times show that since 1998 the Chiripiri has been taking an increasingly larger share of the total surface water. Inset (f) shows that, since 1997, the increase in the sedimentary load has caused a marked increase in the channel width and normalized meander migration rate $(\mathrm{Mr})$ of the Chipiriri. The latter has increased from 0.0122 to 0.0532 . See locations in Fig. 1.

\subsection{Rivers avulsing on a multi-decadal timescale}

The second group comprises rivers with one or two full avulsions since 1984. The Yapacaní, a tributary of the Río Grande, started an avulsion before 1984 in its distal part, about $40 \mathrm{~km}$ before reaching the Grande; it was completed in 1994. The DEM in Fig. 1 shows that the Yapacaní formed a $10000 \mathrm{~km}^{2}$ fan at its exit from the Andes, which, in its middle part, is about $15 \mathrm{~m}$ higher than its surroundings. Other than the Río Grande, the Yapacaní is the only river, of the 12 studied, that created such a large convex up topography.

The Isiboro shows evidence of five distinct crevasses, located between 70 and $85 \mathrm{~km}$ downstream from Villa Tunari. In 1984, when the record begins, a crevasse splay was al- 
Table 3. River characteristics. Catch is the Andean catchment in $\mathrm{km}^{2}$; Sin is the sinuosity measured along the meandering part of the river calculated as the ratio of channel centreline length to the sum of the channel-belt axis lengths, Río Grande and Piraí do not have a long enough meandering reach to allow the measurement; $D$ is the sum of the channel-belt axis lengths from the point at which the river exits the Andes to the point where it reaches its parent river, expressed in kilometre; Slope is the average slope along the river measured as the ratio of the difference in elevation between the point at which the river exits the Andes to the point where it reaches its parent river and $D$, multiplied by 10; Width is the channel width measured along straight sections of the channel, expressed in meters \pm 1 standard deviation; Mr is the average meander migration rate normalized for the channel width, expressed as channel widths per year $\left(\mathrm{ch}^{-} \mathrm{w} \mathrm{yr}^{-1}\right)\left(\mathrm{Constantine} \mathrm{et}^{-1}\right.$ al., 2014); NC is the number of crevasses; $\mathrm{P}$ is the parent river.

\begin{tabular}{lcccccccl}
\hline River & Catch & Sin & $D$ & Slope & Width & Mr & NC & P \\
\hline Chapare & 5321 & 2.57 & 147 & 7.4 & $97.2 \pm 12.63$ & 0.054 & 0 & Mamoré \\
Chimoré & 2092 & 2.10 & 61 & 10.0 & $193.7 \pm 24.19$ & 0.067 & 0 & Mamoré \\
Ichilo & 2603 & 3.16 & 97 & 11.1 & $134.2 \pm 19.35$ & 0.034 & 0 & Mamoré \\
Sacta & 1873 & 2.81 & 51 & 16.1 & $135.7 \pm 12.87$ & 0.051 & 0 & Mamoré \\
Chipiriri & 5049 & 1.67 & 84 & 10.9 & $89.7 \pm 21.79$ & 0.035 & 2 & Isiboro \\
Yapacaní & 6439 & 1.85 & 196 & 6.9 & $72.3 \pm 6.08$ & 0.030 & 1 & Grande \\
Secure & 2479 & 2.14 & 139 & 4.8 & $106.9 \pm 29.19$ & 0.051 & 3 & Isiboro \\
Isiboro & 1419 & 1.99 & 205 & 4.2 & $84.5 \pm 8.88$ & 0.041 & 5 & Mamoré \\
Moleto & 1187 & 2.62 & 116 & 5.5 & - & - & 6 & Isiboro \\
Maniqui & 3534 & 1.73 & 260 & 2.9 & $105.7 \pm 22.18$ & 0.027 & 10 & Yucuma \\
Grande & 62735 & - & 465 & 4.9 & - & - & 7 & Mamoré \\
Piraí & 6439 & - & 290 & 5.5 & - & - & 11 & Grande \\
\hline
\end{tabular}

ready triggering an avulsion. By 2014, when the record ends, the avulsion had not yet been completed, as part of the water still flows through the original channel. The Isiboro is currently depositing its sediments on the invaded flood basin through a sequence of crevasses and avulsions that expand downstream (Fig. 4). More than $200 \mathrm{~km}^{2}$ have been covered with alluvium, causing important changes in the landscape. Figure 4a and b show how, between 1996 and 2013, a lake was completely infilled and erased from the landscape. As the Isiboro receives water from the Chipiriri, which in turn is receiving an increasingly larger share of the water flow of the Chapare, an important part of the sediments that the Chapare used to bring to the Mamoré are instead being deposited on the avulsion belt of the Isiboro.

The Sécure and Moleto rivers' avulsions began by channel annexation, but then changed to a progradational style because the annexed channel was too small to convey the whole diverted flow. Currently, overspills and new crevasse splays are depositing most of the Sécure and Moleto rivers' sedimentary load in the floodplain (Figs. 5, 6).

In the case of the Sécure, a full avulsion, initiated in 1986, was completed in 2006. With this avulsion, the river, which was a tributary of the Mamore, occupied a pre-existing channel and became a tributary of the Río Tijamuchí. This channel is not large enough to accommodate the total flow of the Sécure, causing repeated large floods (Fig. 5) and new crevasse splays and avulsions as part of the process of building a new course (Fig. 5a). The diversion sites are located between 40 and $50 \mathrm{~km}$ downstream from the point where the river enters the alluvial plain, with recent diversion sites forming downstream from the older ones. The planned road

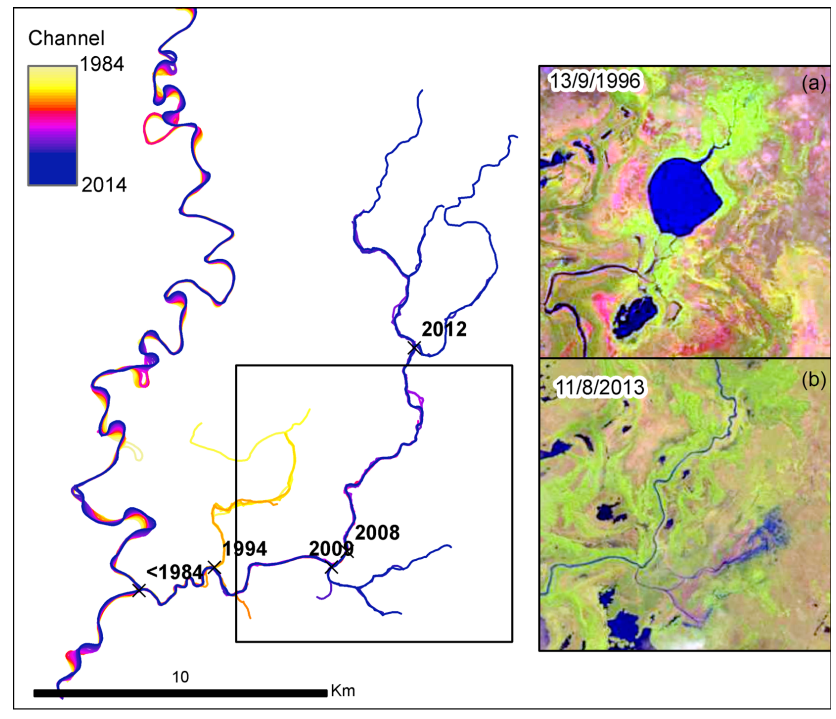

Figure 4. Avulsion of Río Isiboro. The Avulsion has a progradational pattern where new crevasses and avulsions take place downstream from the previous ones. Insets a and $b$ show how the deposition of sediments has reshaped the landscape, completely obliterating a lake.

from Villa Tunari to San Ignacio de Moxos cuts through this very region in which the Sécure is building its new course.

The process of avulsion of the Sécure that was completed in 2006 had devastating effects on local inhabitants, as 20 indigenous communities were settled along the section of the river channel that was cut off. The abandoned channel now holds standing water, triggering a sharp increase in water- 
Table 4. Number of crevasses of the 12 tributaries of the Mamoré versus the rank of the Multivariate ENSO Index (MEI) for every year between 1985 and 2014. For moderate or strong ENSO events, MEI ranks from 1 to 13 would denote La Niña, while ranks from 54 to 66 would denote El Niño. NC is the number of crevasse splays. $\mathrm{N}-\mathrm{D}$ is the MEI rank for the period November-December; D-J is the MEI rank for the period December-January; J-F is the MEI rank for the period January-February.

\begin{tabular}{ccccc}
\hline Year & NC & N-D & D-J & J-F \\
\hline 1985 & 1 & 19 & 22 & 21 \\
1986 & 2 & 28 & 31 & 33 \\
1987 & 0 & 57 & 60 & 60 \\
1988 & 2 & 60 & 56 & 51 \\
1989 & 0 & 5 & 7 & 6 \\
1990 & 2 & 37 & 39 & 49 \\
1991 & 0 & 40 & 42 & 41 \\
1992 & 0 & 62 & 64 & 64 \\
1993 & 3 & 48 & 52 & 58 \\
1994 & 3 & 46 & 43 & 39 \\
1995 & 1 & 58 & 59 & 57 \\
1996 & 0 & 22 & 18 & 23 \\
1997 & 3 & 26 & 25 & 22 \\
1998 & 0 & 64 & 65 & 65 \\
1999 & 0 & 13 & 8 & 9 \\
2000 & 1 & 8 & 6 & 8 \\
2001 & 2 & 21 & 23 & 16 \\
2002 & 3 & 34 & 36 & 32 \\
2003 & 0 & 56 & 58 & 56 \\
2004 & 0 & 39 & 41 & 42 \\
2005 & 0 & 49 & 40 & 52 \\
2006 & 2 & 20 & 27 & 25 \\
2007 & 2 & 53 & 55 & 48 \\
2008 & 4 & 9 & 13 & 4 \\
2009 & 1 & 17 & 16 & 15 \\
2010 & 4 & 54 & 57 & 63 \\
2011 & 1 & 4 & 2 & 2 \\
2012 & 2 & 14 & 11 & 17 \\
2013 & 1 & 35 & 38 & 34 \\
2014 & 1 & 27 & 29 & 31 \\
\hline & & & & \\
& & \\
199 & \\
1990
\end{tabular}

borne diseases and limiting peoples' access to fish resources and navigation courses (Sécure, el río se está muriendo, Escape - Diario La Razón, http://la-razon.com/suplementos/, last access: 15 March 2016).

The Moleto is a tributary of the Río Isiboro. The analysis of satellite images shows that since 1988 six crevasses have opened up, three of which initiated a process of avulsion. These are located between 6 and $60 \mathrm{~km}$ from the point at which the river exits the Andes. In 1988 a crevasse started an avulsion process that went on for 12 years (Fig. 5). This process was interrupted in the year 2000, when the Moleto annexed a pre-existing channel and avulsed about $60 \mathrm{~km}$ upstream from the 1988 diversion site (Fig. 5). The annexed channel is unable to accommodate the Moleto, hence, soon after the avulsion was completed in 2001 , a series of pro-

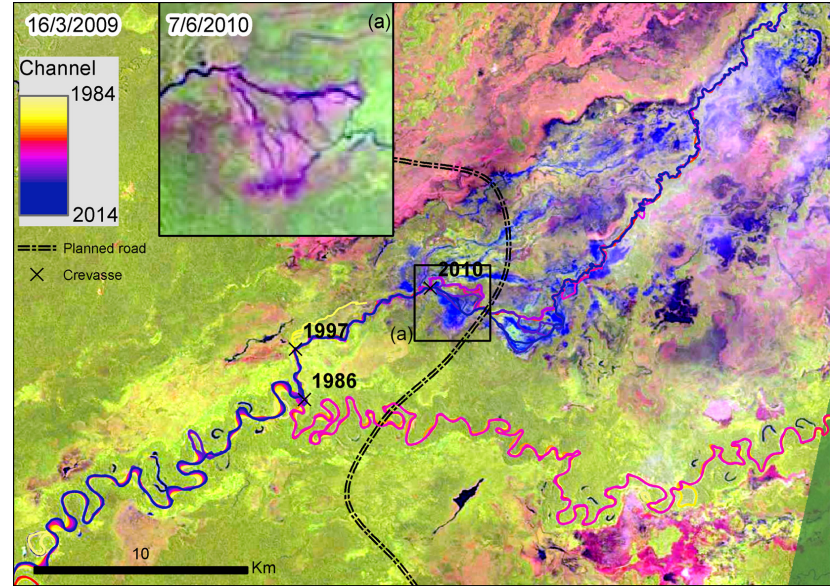

Figure 5. Avulsions of the Río Sécure. River overflow and new crevasses form large floods (bluish areas) along the annexed channel. The planned road from Villa Tunari to San Ignacio will cut through this area.

cesses started to transform the original channel. In the upper part, the new flow has been accommodated by the preexisting channel thanks to the formation of larger meanders (Fig. 6c). At about $30 \mathrm{~km}$ downstream from the diversion site, the channel collapses into a series of crevasses (Fig. 6d, e). Two scenarios are possible for the evolution of the Río Moleto. The partial avulsion that began in 2002 (Fig. 6a) could be completed and the river could establish a new course further north, or the 2002 crevasse could heal and the totality of the river's water and sedimentary load would then go to the channel annexed in the year 2000. If the latter case takes place, it is likely that there will be another avulsion about the middle of the annexed channel, where crevasse sites are currently moving backwards (Fig. 6d, e). As most of the sediments are deposited through crevasses along the annexed channel, and most of the water is diverted into the floodplain, the second half of the pre-existing channel does not show any change in its meandering rate (Fig. 6b). The planned road from Villa Tunari to San Ignacio will cut through the Moleto's avulsion belt, as well as the Secure's avulsion belt (Fig. 6).

\subsection{Rivers avulsing on a sub-decadal timescale}

Rivers belonging to the third group, the Maniqui, the Piraí and the Grande, show a decreasing discharge downflow, forming distributive fluvial systems (DFS) (Nichols and Fisher, 2007; Hartley et al., 2010), with avulsions completed immediately after the formation of the crevasses. The term DFS refers to any deposit of a fluvial system which in planform displays a radial, distributive channel pattern (Hartley et al., 2010).

The Río Maniqui is the first river south of Río Beni. The Maniqui's paleo-channels cover a large extent of the west- 


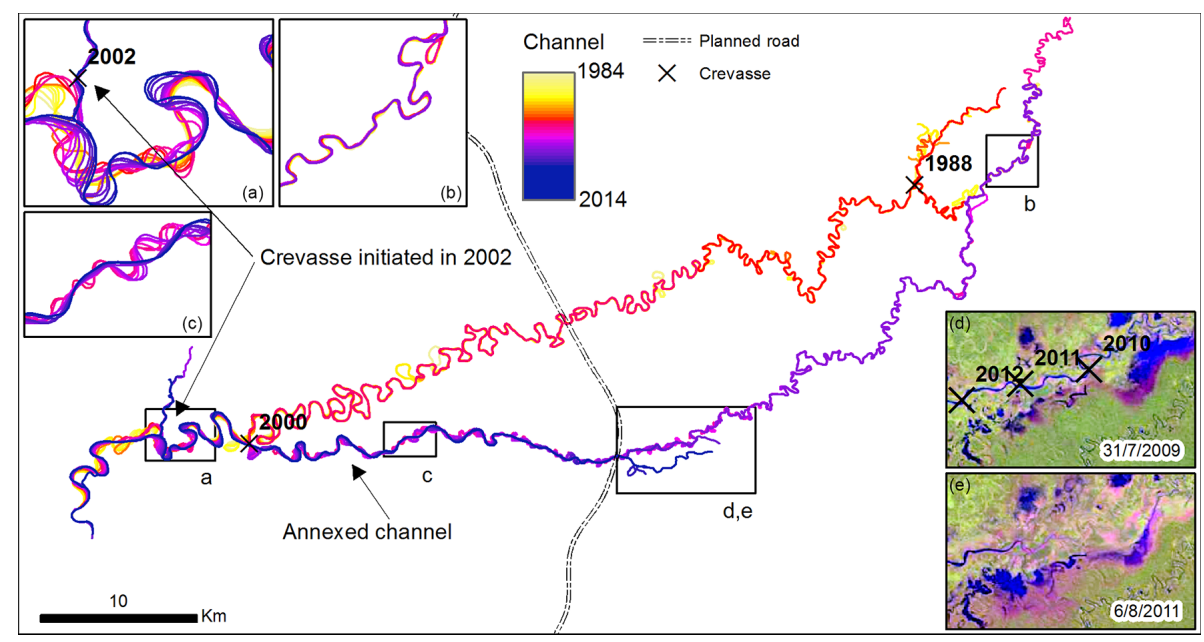

Figure 6. Avulsions of the Río Moleto. The channel annexed in the year 2000 adjusted the upper part of its course (c), but is unable to carry the total flow in the middle part of the channel, where several crevasses have opened up, causing the collapse of the channel and the deposition of the sedimentary load (d, e). A crevasse initiated in 2002, upstream from the current diversion site (a), and is leading to a process of avulsion that could be completed in the next decade. Reddish areas in the Landsat images of insets $d$ and e show dead forest due to waterlogging. See location in Fig. 1.

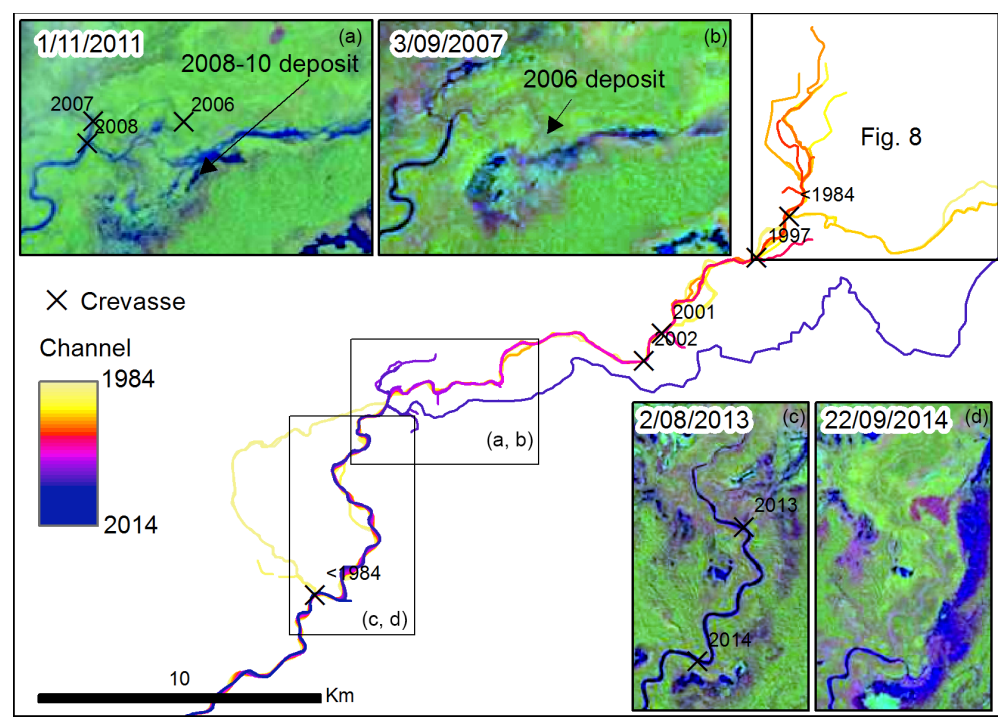

Figure 7. The Río Maniqui. Insets (a) and (b) show crevasse splay deposits which are immediately covered with vegetation. Insets (c) and (d) show the backward movement of the crevasse point and the sudden collapse of the original channel. The blue area to the right of inset (d) is a depression that has been flooded because of the crevasse opened in 2014. After the crevasse of 2008 the river avulsed and took a new course, but the new course lasted only until the crevasses of 2013 and 2014 (insets $\mathbf{c}$ and d) re-established the backward trend.

ern part of the LM (Fig. 1). Up to date, the only study describing the Maniqui is a report by Hanagart and Sarmiento (1990) where they notice that, during the rainy season, the Maniqui's overflow forms sheet-floods of turbid water that reach the Río Rápulo as black waters after being filtered by the vegetation. In the last 30 years this river has been highly active. A total of 10 crevasse splays have been identified, seven of which led to an avulsion (Fig. 7). These are located between 60 and $90 \mathrm{~km}$ downstream from the point at which the Maniqui enters the alluvial plain. Two crevasses opened up before 1984. Until 1994, the Maniqui was connected with the Rápulo, which is a tributary of the Mamoré. The connection with the Rápulo was lost when the avulsion that started with the pre-1984 crevasse was completed and the former channel was abandoned. Since then, the location of the crevasse splays has gradually moved upriver. The location of the 2014 crevasse is approximately $30 \mathrm{~km}$ southeast of the 1997 one (Fig. 7). Following this upward move- 


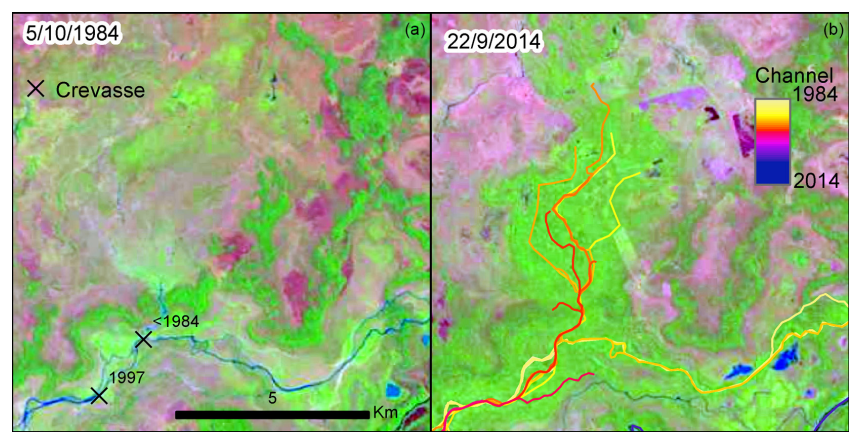

Figure 8. Change in vegetation cover from savannah (reddish) to forest (green). The area covered with savannah in 1984 (a) becomes forested (b) after sediments are deposited by crevasses in the central part of the image. In inset (b), paleo courses from 1984 to 1999 are drawn.

ment of the levee breakage, new areas of the alluvial plain have been flooded by the Maniqui every year. Those areas that have been flooded for several consecutive years, for example, the region in the upper part of Fig. 7 between 1984 and 1997, show a change in the land cover from savannah to forest (Fig. 8) due to the deposition of alluvium and a change in the topography. The forest growing on the 19841997 alluvium covers more than $10 \mathrm{~km}^{2}$. However, changes in topography are measurable even when the flooding is limited to a single year. Inset (b) in Fig. 7 shows that the 2006 floods created a vegetated splay of $0.47 \mathrm{~km}^{2}$. The width of the Río Maniqui when it reaches the town of San Borja is $105 \mathrm{~m}$ (measured using images taken in July 2013), but drops to $70 \mathrm{~m}$ just before reaching the crevasse of 2008 , which is only $40 \mathrm{~km}$ down valley from San Borja. This suggests that river discharge decreases along this $40 \mathrm{~km}$ stretch. Figure 7 shows that crevasses immediately followed by avulsions can happen on a yearly basis. The drop in river discharge and the frequency of avulsions suggest that the channel becomes perched during the dry season. Therefore, it can be inferred that while the infilling of the channel progresses, the point of the next siltation/logjam formation moves upstream and so does the location of the next crevasse. This sequence of events probably continues until the crevasse opens up at a point where the discharge is large enough to force a full avulsion, limiting the formation of other crevasses upstream. Given the speed at which crevasses are moving upstream, it will probably be less than a couple of decades before the river takes a completely new course.

Río Piraí is the most important of all the rivers studied in terms of potential threat to the population, as it goes through Santa Cruz de la Sierra, the largest city in Bolivia, with about $1.5 \mathrm{~m}$ inhabitants. In the past, floods of the Piraí have caused huge economic losses (Latrubesse et al., 2009b). Since 1986, there have been 11 crevasses, located between 50 and $110 \mathrm{~km}$ downstream of the point in which the Piraí enters the alluvial plain. Of these 11 crevasses 9 initiated an avulsion.

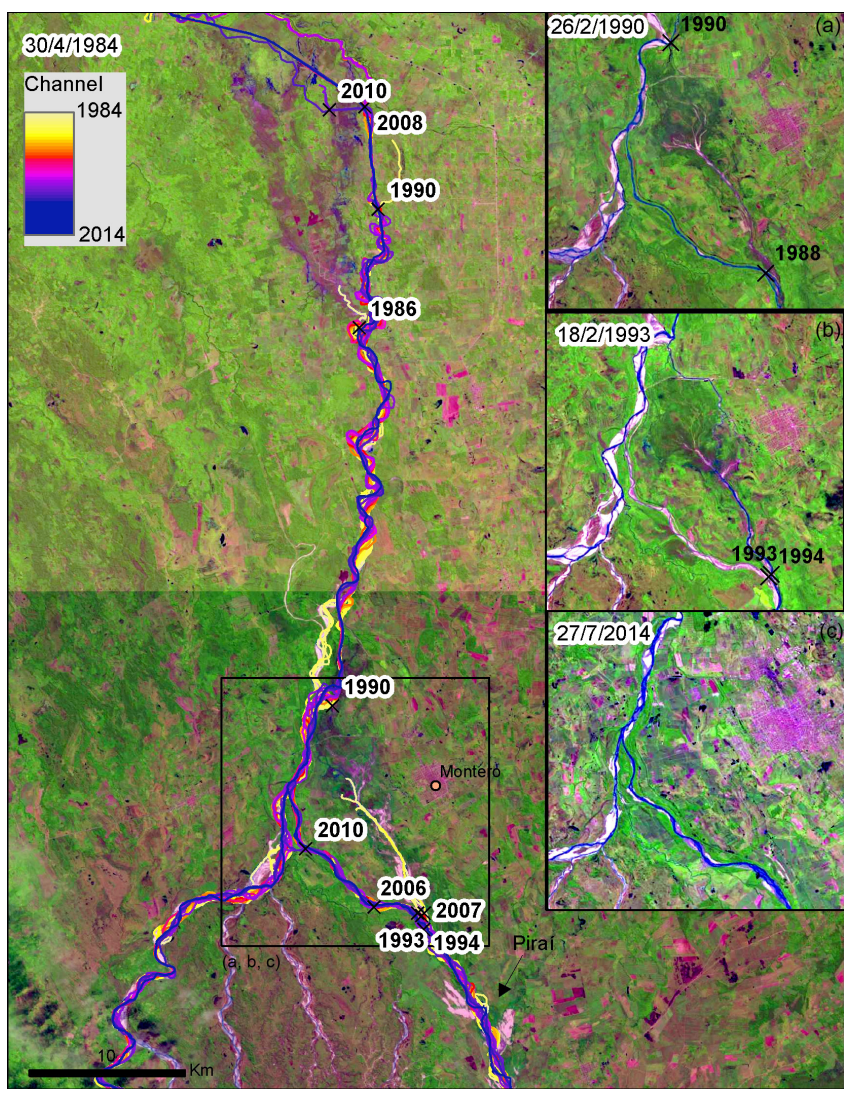

Figure 9. Avulsions of the Río Piraí. There are two regions where crevasse splays and avulsions are taking place, in the proximity of the town of Montero (insets a-c), and about $30 \mathrm{~km}$ north. In the more distal zone, the Piraí has formed several different avulsive courses, causing large floods. In the last decade the river channel has been straightened by farmers (upper part of the figure), in an attempt to control the floods.

The crevasse splays are concentrated in two regions: one in the proximity of the city of Montero and another one about $30 \mathrm{~km}$ further north (Fig. 9). During the period between 1977 and 1981, measurements at gauging stations located before and after Montero showed an increase in the annual discharge from 13 to $20 \mathrm{~m}^{3} \mathrm{~s}^{-1}$. The total suspended sediments (TSS), on the other hand, showed a decrease of more than $50 \%$ (Guyot et al., 1994). The reduction in the TSS of the Piraí is probably larger than $50 \%$, as several rivers join the $\mathrm{Pi}$ raí between the two stations. Between 1984 and 1988, the southern part of the river ended in a terminal crevasse just a couple of kilometres west of Montero (Fig. 9a). An avulsion in 1988, which was completed in 1990 , now connects the two reaches of the river. This new setting is maintained until 2014, with the exception of 1993 when the river briefly switched back to the pre-1988 channel for 1 year (Fig. 9b, c). The aggradational area occupied by the crevasse splay deposits close to Montero is now under cultivation and the city of Montero has greatly expanded, occupying the very same 
areas that were under severe flooding and high rates of sediment deposition until 1993. In the northern reach, a crevasse in 1986 caused the flooding of a large area and the death of the vegetation cover (reddish area in Fig. 9). After a second crevasse in 1990, the river underwent two consecutive avulsions in 2008 and 2010. The river channel has been artificially straightened, first in 2010 and again in 2013 (see upper part of Fig. 9). If it persists, this artificial straightening of the river channel will probably push the zone of future crevasses and avulsions further downstream.

Río Grande, the most south-eastern of the 12 tributaries, has by far the largest Andean catchment of all the Mamoré tributaries and, at the town of Abapo, where the river enters the alluvial plains, it carries $138 \mathrm{Mtyr}^{-1}$ of TSS (Guyot et al., 1996). The Río Grande exits the Andes forming braided channels and becomes a single-thread channel at about the same point where avulsions begin (Fig. 10). From 1984 to 2014 there have been six crevasse splays, located between 240 and $270 \mathrm{~km}$ downstream of Abapo. Except for the first one in 1986, all the crevasses led to avulsions. The first avulsion took place in 1993. In 2008, after the last recorded avulsion, the Río Grande established its modern course. It has been estimated that about half of the Río Grande's TSS is deposited in the floodplain after its exit from the Andes (Guyot et al., 1996). The estimate is based on the comparison of measurements between a gauging station located at Abapo, on the Río Grande (AP, TSS $138 \mathrm{Mtyr}^{-1}$; discharge $330 \mathrm{~m}^{3} \mathrm{~s}^{-1}$ ), and a station on the Mamoré, in the proximity of Trinidad (PG - Río Mamoré at Puerto Varador, TSS $63 \mathrm{Mt} \mathrm{yr}^{-1}$; discharge $2970 \mathrm{~m}^{3} \mathrm{~s}^{-1}$ ) (Guyot et al., 1996). These data have been used by several authors to estimate the amount of sediment deposition along the Grande-Mamoré system. Charriere et al. (2004) have estimated that the Mamoré River deposits about $150 \mathrm{Mtyr}^{-1}$ along the first $200 \mathrm{~km}$ of its course downstream of Puerto Villarroel (i.e. before reaching the PG gauging station); while Constantine et al. (2014) have estimated that Río Grande provides $84 \%$ of the TSS of the Mamoré at PG. These estimates implicitly assume that other tributaries of the Mamoré (several other rivers joining the Río Grande and the Mamoré between Abapo and Trinidad: the Ichilo, the Piraí, the Chimoré, the Chapare, the Sacta, the Isiboro and the Yapacaní) do not represent an important contribution to its TSS at the PG gauging station. On the contrary, the new data coming from the analysis of Landsat imagery suggest that most of the Mamorés TSS at the station PG does not come from the Río Grande but from the other tributaries. The analysis of the meander migration rate of the Río Grande just before joining the Mamoré (Fig. 11) suggests that, through the repeated formation of crevasses and avulsions, almost all of the Río Grande's TSS is deposited in the alluvial plains before it reaches the Mamoré, forming alluvial deposits and extensive dune fields (May 2013; Latrubesse et al., 2012). Immediately before the Río Grande joins the Mamoré, it receives water from the Río Yapacaní. The average meander migration rates of the Río Grande before and

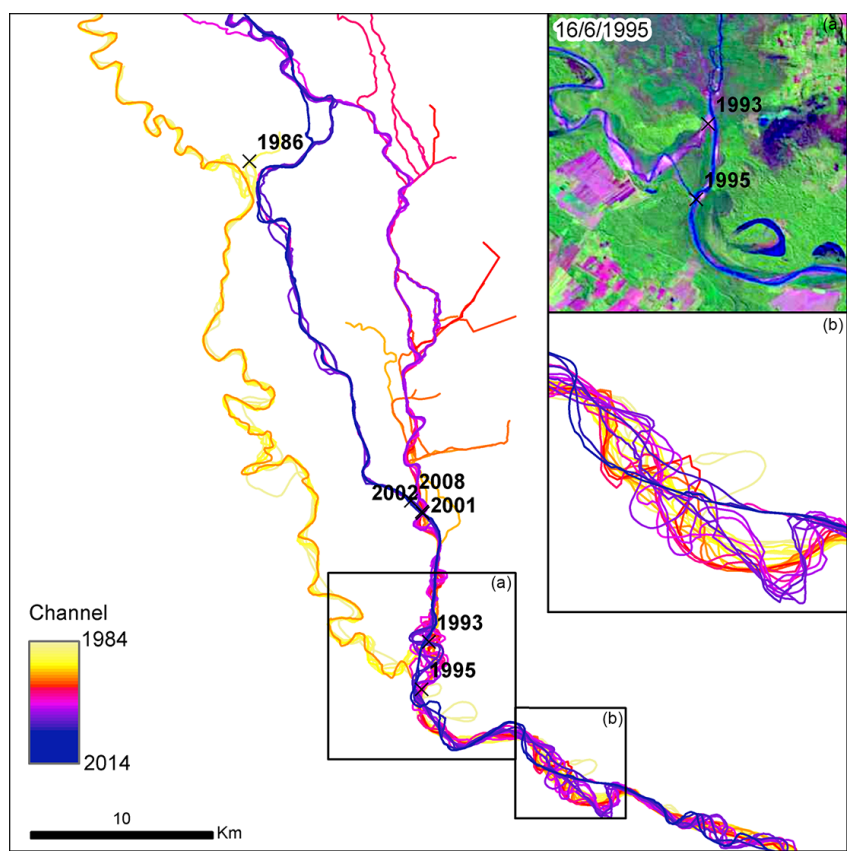

Figure 10. Avulsions and crevasses of the Río Grande. Inset (b) shows that the Río Grande has a multithreaded channel until it reaches the point of the 1995 crevasse.

after receiving water from the Yapacaní are $0.46 \pm 0.4$ and $3.53 \pm 2.9 \mathrm{~m} \mathrm{yr}^{-1}$ respectively. This shows that an important part of the sediments that the Río Grande brings to the Mamoré actually come from the Yapacaní. In addition, although data on the TSS of the rivers joining the Río Grande and the Mamoré between Abapo and Trinidad are very limited, these rivers cause an almost tenfold increase in river discharge from AP $\left(330 \mathrm{~m}^{3} \mathrm{~s}^{-1}\right)$ to PG $\left(2970 \mathrm{~m}^{3} \mathrm{~s}^{-1}\right)$. Therefore, several observations suggest that far more than the previously estimated $50 \%$ of the sediments that the Río Grande brings from the Andes are sequestered in the alluvial plains before reaching the Mamoré: (i) the important contribution of the other tributaries to the Mamoré's discharge; (ii) the high meandering rate of some of them; (iii) the high number of crevasses and avulsions experienced by Río Grande; and (iv) the changes in Río Grande's Mr in the proximity of its connection with the Yapacaní.

\section{Discussion}

In aggrading alluvial plains characterized by the presence of well-developed paleosols within fine-grained alluvium, as it is the case in the SAFB (Lombardo et al., 2012; Lombardo, 2014), crevasse splays and river avulsions are the most important depositional processes in alluvial plains (Slingerland and Smith, 2004; Smith et al., 1989). Despite a large body of studies, the exact mechanisms controlling crevasse splays and river avulsions are not entirely understood (Hajek and Edmonds, 2014; Stouthamer and Berendsen, 2007; Ash- 


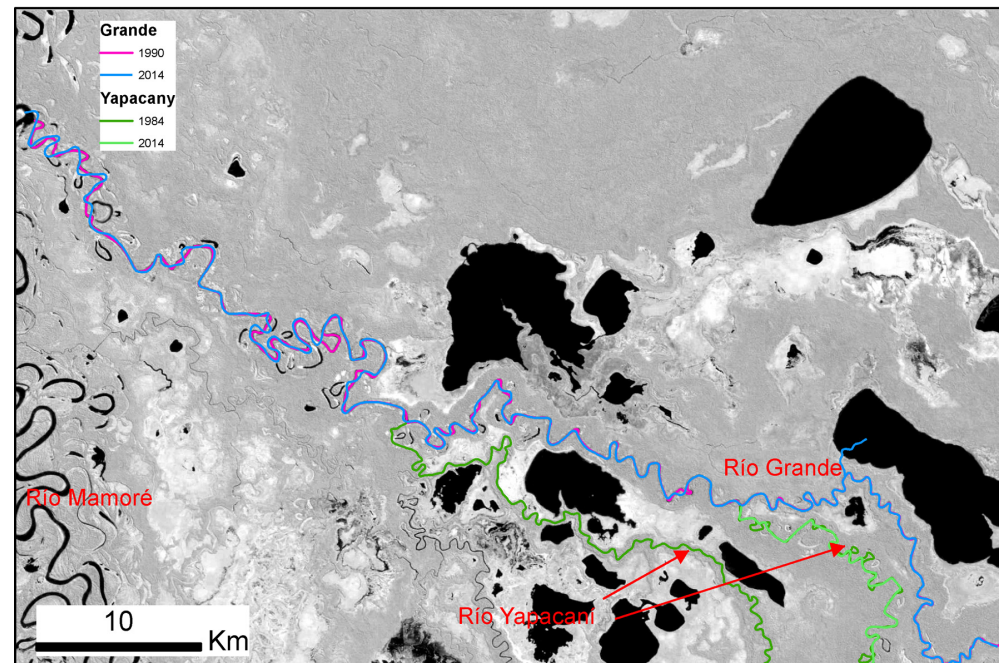

Figure 11. The last reach of the Río Grande before joining the Mamoré. The comparison between the 1990 and the 2014 Río Grande channels before and after the connection with the Río Yapacaní shows that most of the meandering of the Río Grande, when it reaches the Mamoré, is due to the sedimentary load brought by the Yapacaní.

worth et al., 2004). When the various processes that push the river towards the avulsion threshold proceed at a faster pace than those that act as triggers, the latter control the frequency of crevasses and, eventually, avulsions (Jones and Schumm, 1999). It is generally accepted that in southern Amazonia the trigger behind the formation of crevasses in large rivers is the sudden increase in river discharge that follows extreme precipitation events linked to La Niña (Aalto et al., 2003). In the SAFB, research suggests that the frequency of river crevasse formation increases during la Niña events (Aalto et al., 2003), because higher precipitation in the eastern flanks of the Andes is accompanied by reduced precipitation in the lowlands. This increased precipitation towards the Andes causes an important rise in the rivers' discharge, whilst the floodplain water table remains relatively low. Under these conditions, the formation of crevasses becomes more likely because the water level inside the river channel rises faster than the water level in the surrounding floodplain (Aalto et al., 2003). The thick deposits of sediment in the Mamoré and Beni floodplains are believed to be the result of crevasse splays and sheet sand deposits that formed in this way (Aalto et al., 2003; Aalto and Nittrouer, 2012). Hence, Aalto et al. (2003) conclude that these deposits, triggered by La Niña events, cause most of the flood-plain sediment accumulation across the lowland plains. However, the validity of this hypothesis has been challenged by Gautier et al. (2007), who did not find any visible evidence of crevassesplay formations along the Beni River, although their field coring efforts were limited to a single transect on the lower limb of an active meander.

The new data here presented challenges both the importance of large rivers in controlling alluvial plain dynamics in the lowland plains of the SAFB and the role of La Niña in controlling the timing of crevasse splays.

The results of this study, combined with other published data (Guyot et al., 1996; Lombardo, 2014; do Nascimento Jr. et al., 2015; Plotzki et al., 2015), suggest that these small rivers are highly active and play a dominant role in shaping the SAFB alluvial plains. These rivers, and in particular the Sécure, Isiboro, Moleto, Maniqui, Piraí and Grande rivers, show extremely reduced meander migration rates downstream from where the crevasses opened up (for example Fig. 6), probably as a consequence of a decrease in their sedimentary load, following the same pattern described for rivers in other geologic and climatic settings (Smith et al., 1989; Buehler et al., 2011). Most of the sediments, along with associated nutrients and carbon, eroded from the Andean catchment of the Mamoré are therefore sequestered in the flood plains of its tributaries through the formation of crevasse splays and avulsions. This can explain why about half of the total sediment flux discharged from the Bolivian Andes is deposited in the SAFB (Guyot et al., 1996), including most of the sand fraction (do Nascimento Jr. et al., 2015). It also explains why the Río Beni, which only has one tributary with a catchment in the Andes (the Río Madidi), brings to the Madeira three times more sediments than the Mamoré (Guyot et al., 2007; Aalto et al., 2002), despite the fact that the Beni has a smaller catchment and an average water discharge of $3070 \mathrm{~m}^{3} \mathrm{~s}^{-1}$, versus the $5080 \mathrm{~m}^{3} \mathrm{~s}^{-1}$ of the Mamoré (Guyot et al., 1996). This reinforces the observation that, in the mid Holocene, the tributaries of the Mamore deposited thick layers of sediments over the southern and central part of the LM (Lombardo, 2014). This research adds new evidence to the idea that most of the modern continental sedimentary basins are filled primarily by DFS (Weissmann 
et al., 2013; Hartley et al., 2010) and shows that the SAFB is an excellent natural laboratory for the study of river processes in sedimentary basins.

The study of the tributaries of the Mamoré over a period of 30 years shows no link between the timing of the crevasses and La Niña events (Table 2). The behaviour of the rivers Maniqui, Piraí and Grande seems to be controlled by the seasonal lowering of the water table, below stream level, during the dry season. This causes the river to leak water from its channel into the ground beneath, causing a reduction in the rivers' sediment transport capacity, increased channel infilling and likelihood of logjam formations. However, as described in the case of Río Pilcomayo in the Chaco plains, which shows a similar seasonal behaviour (Martín-Vide et al., 2014), increased sediment discharge due to modern land use changes in the Andes could also contribute to the channel infilling. The behaviour of the studied rivers suggests that, on an annual to decade timescale, the activity of southern Amazonian small rivers is controlled by bed aggradation and logjams. These are likely caused by the rivers' high sedimentary load combined with a perched channel during the dry season and an extremely low along-valley slope, which not only bring the rivers to the threshold conditions for the formation of crevasse splays, but also trigger the crevasses. In this setting, the decrease in average precipitation over the SAFB experienced in recent years (Espinoza Villar et al., 2009) and the lengthening of the dry season (Fu et al., 2013) increase the frequency of river crevasses and move their formation closer to the Andes. The fact that all the modern crevasses are closer to the Andes than the mid- to late Holocene distributary systems formed by the rivers in groups 2 and 3 suggests, on a millennial scale, a common climatic (Mayle et al., 2000; Baker, 1977) and/or neo-tectonic (Lombardo, 2014; Dunne et al., 1998) control over the shifting of these rivers' depozone. A lack of discrete deposition events has been reported along the Mamoré floodplain after 1971, which could have been caused by a change in regional climate that took place around this time (Aalto et al., 2003). Thus, further research is needed in order to assess whether and how this change could have affected the dynamics of the Mamore tributaries. Further research is also needed in order to better understand the exact mechanisms behind the formation of crevasses; the contribution of La Niña driven sheet sand deposits to the total floodplain sediment deposition of the Mamorés tributaries; and the shift of the tributaries' sedimentary depozones.

The evolution of the fluvial network and the constant and frequent changes in river connectivity can have important effects on forest disturbance, aquatic ecosystems and the indigenous populations that live along these rivers. The topographic changes caused by the deposition of fluvial sediments have immediate effects on the local forest-savannah ecotone, which is largely controlled by topography (Mayle et al., 2007). Crevasse splays form on the lower part of the landscape, which is normally covered with savannah vegetation. But, as the sediments are deposited, an elevated area is cre- ated that eventually becomes forested (Figs. 7, 8). Likewise, crevasses and avulsions cause the flooding, and hence dieoff, of large areas of forest (see for example the reddish area in the upper part of Fig. 9). Aquatic animals, especially migratory fish, must continuously adapt to the frequent changes in the fluvial network. The regime of continuous river fragmentation and forest disturbance could explain the unusually high fish and plant biodiversity found in this area (Pouilly et al., 2004; Thomas, 2009).

It is important that Bolivian policy makers take into account the dynamics of the SAFB's river network in order to mitigate future risks to the local population and to better assess the feasibility of new development plans. In particular, river avulsions can have catastrophic consequences on indigenous communities, as shown in the case of the Sécure. If the trend in the formation of new crevasses continues in the future, it is likely that the rivers Maniqui, Moleto and Isiboro will change their course in the next decade or two. When this happens, the indigenous communities settled along these rivers will have to be relocated. The frequent avulsions of the Piraí following the 1988, 1993 and 1994 crevasses suggest that it could avulse again in the near future in this same diversion site, flooding the city of Montero, with important economic and human costs. The planned highway cutting through the Territory and National Park Territorio Indígena y Parque Nacional Isiboro-Secure (TIPNIS) has received strong protests, for and against it (see for example http: //www.bbc.com/news/world-latin-america-15138784 and http://www.bbc.com/news/world-latin-america-16804399).

Nevertheless, the technical feasibility of the project has received little attention. The road, linking Villa Tunari to San Igancio de Moxos, will go through areas that are under constant threat of major floods resulting from the frequent formation of crevasse splays and the avulsion of the rivers Moleto and Sécure (Figs. 5, 6). It is likely that, if built, the road will require costly and continuous maintenance. Moreover, the road will dam these rivers, with unpredictable effects on the aquatic ecosystems of this still largely pristine environment.

\section{Conclusions}

This paper analyses the behaviour of 12 southern Amazonian small rivers and their role in the formation of the SAFB alluvial plains. Several studies about alluvial plain dynamics in Amazonia have focused on large rivers, concluding that they cause most of the alluvial plain sediment accumulation. It has been proposed that this sedimentation is primarily the result of crevasse splays and sheet sand deposits triggered by large, rapid-rise ENSO floods. The analysis of the 12 tributaries of the Río Mamoré over a period of 30 years shows that these rivers are extremely active, continuously reshaping the landscape, with immediate effects on the local topography, the forest-savannah ecotone and the region's biodiver- 
sity. Most of the sediments that these rivers bring from the Andes are sequestered in the alluvial plains before they reach the Mamoré. In contrast with what has been reported for the Mamoré and Beni rivers in previous studies, in the case of the smaller tributaries no correlation emerges between the frequency of crevasse splays and ENSO events. In the case of the southern Amazonian small rivers, the frequency of crevasse splays and avulsions is controlled by intrabasinal processes on a yearly to decadal timescale, while their location, i.e. the average down-valley distance from the Andes where crevasses form, is controlled by climate and tectonic activity on a millennial scale. Small rivers' fluvial activity greatly affects the livelihoods of rural communities, particularly indigenous people who are often settled along these rivers and dependent on their resources. The study has shown how river avulsions can have a catastrophic impact on communities settled on the reach of the river that is cut-off. On the other hand, these highly active rivers have also favoured agricultural development in some areas, through the deposition of fertile sediments. It is important that alluvial plain dynamics are taken into account by policy makers and development organisations in Bolivia, particularly when planning major infrastructure projects in the area. In light of the study's results, it should be advisable that the technical feasibility of the planned road linking Villa Tunari to San Ignacio de Moxos is re-assessed.

Acknowledgements. The present study has been funded by the Swiss National Science Foundation (SNSF) grant no P300P2158459/1. I would like to thank Elisa Canal-Beeby who helped improve earlier versions of the manuscript. I would also like to thank the handling editor, R. Aalto, the first reviewer Jim Pizzuto and the anonymous second reviewer for their suggestions on how to improve the manuscript.

Edited by: R. Aalto

\section{References}

Aalto, R. and Nittrouer, C. A.: 210Pb geochronology of flood events in large tropical river systems, Philos. T. Roy. Soc. A, 370, 2040 2074, doi:10.1098/rsta.2011.0607, 2012.

Aalto, R., Dunne, T., Nittrouer, C. A., Maurice-Bourgoin, L., and Montgomery, D. R.: Fluvial transport of sediment across a pristine tropical foreland basin: channel-floodplain interaction and episodic floodplain deposition, in: The Structure, Function and Management Implications of Fluvial Sedimentary Systems, Wallingford, UK, IAHS Publ. no. 276, 339-344, 2002.

Aalto, R., Maurice-Bourgoin, L., Dunne, T., Montgomery, D. R., Nittrouer, C. A., and Guyot, J.-L.: Episodic sediment accumulation on Amazonian flood plains influenced by El Niño/Southern Oscillation, Nature, 425, 493-497, doi:10.1038/nature01990, 2003.

Ashworth, P. J. and Lewin, J.: How do big rivers come to be different?, Earth-Sci. Rev., 114, 84-107, doi:10.1016/j.earscirev.2012.05.003, 2012.
Ashworth, P. J., Best, J. L., and Jones, M.: Relationship between sediment supply and avulsion frequency in braided rivers, Geology, 32, 21-24, doi:10.1130/g19919.1, 2004.

Baker, V. R.: Adjustment of fluvial systems to climate and source terrain in tropical and subtropical environments, in: Fluvial Sedimentology, Memoir-Canadian Society of Petroleum Geologists, edited by: Miall, A. D., Calgary, Canada, 211-230, 1977.

Buehler, H. A., Weissmann, G. S., Scuderi, L. A., and Hartley, A. J.: Spatial and Temporal Evolution of an Avulsion on the Taquari River Distributive Fluvial System from Satellite Image Analysis, J. Sediment. Res., 81, 630-640, doi:10.2110/jsr.2011.040, 2011.

Carson, J. F., Whitney, B. S., Mayle, F. E., Iriarte, J., Prümers, H., Soto, J. D., and Watling, J.: Environmental impact of geometric earthwork construction in pre-Columbian Amazonia, P. Natl. Acad. Sci. USA, 111, 10497-10502, doi:10.1073/pnas.1321770111, 2014.

Charriere, M., Bourrel, L., Gautier, E., and Pouilly, M.: División geomorfológica del Río Mamoré, in: Diversidad biológica en la llanura de inundación del Río Mamoré, edited by: Pouilly, M., Beck, S. G., Moraes, M., and Ibañez, C., Importancia ecológica de la dinámica fluvial, Fundacíon Simón I. Patiño, La Paz, 7794, 2004.

Constantine, J. A., Dunne, T., Ahmed, J., Legleiter, C., and Lazarus, E. D.: Sediment supply as a driver of river meandering and floodplain evolution in the Amazon Basin, Nat. Geosci., 7, 899-903, doi:10.1038/ngeo2282, 2014.

do Nascimento Jr., D. R., Sawakuchi, A. O., Guedes, C. C. F., Giannini, P. C. F., Grohmann, C. H., and Ferreira, M. P.: Provenance of sands from the confluence of the Amazon and Madeira rivers based on detrital heavy minerals and luminescence of quartz and feldspar, Sediment. Geol., 316, 1-12, doi:10.1016/j.sedgeo.2014.11.002, 2015.

Dunne, T., Mertes, L. A. K., Meade, R. H., Richey, J. E., and Forsberg, B. R.: Exchanges of sediment between the flood plain and channel of the Amazon River in Brazil, Geol. Soc. Am. Bull., 110, 450-467, doi:10.1130/00167606(1998)110<0450:eosbtf>2.3.co;2, 1998.

Espinoza, J. C., Chavez, S., Ronchail, J., Junquas, C., Takahashi, K., and Lavado, W.: Rainfall hotspots over the southern tropical Andes: Spatial distribution, rainfall intensity, and relations with large-scale atmospheric circulation, Water Resour. Res., 51, 3459-3475, doi:10.1002/2014wr016273, 2015.

Espinoza Villar, J. C., Guyot, J. L., Ronchail, J., Cochonneau, G., Filizola, N., Fraizy, P., Labat, D., de Oliveira, E., Ordoñez, J. J., and Vauchel, P.: Contrasting regional discharge evolutions in the Amazon basin (1974-2004), J. Hydrol., 375, 297-311, doi:10.1016/j.jhydrol.2009.03.004, 2009.

Espurt, N., Baby, P., Brusset, S., Roddaz, M., Hermoza, W., Regard, V., Antoine, P. O., Salas-Gismondi, R., and Bolaños, R.: How does the Nazca Ridge subduction influence the modern Amazonian foreland basin?, Geology, 35, 515-518, doi:10.1130/g23237a.1, 2007.

Fu, R., Yin, L., Li, W., Arias, P. A., Dickinson, R. E., Huang, L., Chakraborty, S., Fernandes, K., Liebmann, B., Fisher, R., and Myneni, R. B.: Increased dry-season length over southern Amazonia in recent decades and its implication for future climate projection, P. Natl. Acad. Sci. USA, 110, 18110-18115, doi:10.1073/pnas.1302584110, 2013. 
Gautier, E., Brunstein, D., Vauchel, P., Roulet, M., Fuertes, O., Guyot, J. L., Darozzes, J., and Bourrel, L.: Temporal relations between meander deformation, water discharge and sediment fluxes in the floodplain of the Rio Beni (Bolivian Amazonia), Earth Surf. Proc. Land., 32, 230-248, 2007.

Guyot, J. L., Bourges, J., and Cortez, J.: Sediment transport in the Rio Grande, an Andean river of the Bolivian Amazon drainage basin, in: Variability in Stream Erosion and Sediment Transport, IAHS Press, Canberra, IAHS Publ. no. 224, 223-231, 1994.

Guyot, J. L., Filizola, N., Quintanilla, J., and Cortez, J.: Dissolved solids and suspended sediment yields in the Rio Madeira basin, from the Bolivian Andes to the Amazon, in: Erosion and Sediment Yield: Global and Regional Perspect, IAHS publ., Exeter, IAHS Publ. no. 236, 55-63, 1996,

Guyot, J. L., Jouanneau, J. M., Soares, L., Boaventura, G. R., Maillet, N., and Lagane, C.: Clay mineral composition of river sediments in the Amazon Basin, Catena, 71, 340-356, doi:10.1016/j.catena.2007.02.002, 2007.

Hajek, E. A. and Edmonds, D. A.: Is river avulsion style controlled by floodplain morphodynamics?, Geology, 42, 199-202, doi:10.1130/g35045.1, 2014.

Hanagarth, W.: Acerca de la geoecología de las sabanas del Beni en el noreste de Bolivia, Instituto de ecología, La Paz, 1993.

Hanagart, W. and Sarmiento, J.: Reporte preliminar sobre la geoecología de la sabana de Espíritu y sus alrededores (Llanos de Moxos, departamento del Beni, Bolivia), Ecología en Bolivia, 16, 47-75, 1990.

Hartley, A. J., Weissmann, G. S., Nichols, G. J., and Warwick, G. L.: Large Distributive Fluvial Systems: Characteristics, Distribution, and Controls on Development, J. Sediment. Res., 80, 167-183, doi:10.2110/jsr.2010.016, 2010.

Herzog, S., Maillard, Z. O., Embert, D., Caballero, P., and Quiroga, D.: Range size estimates of Bolivian endemic bird species revisited: the importance of environmental data and national expert knowledge, J. Ornithol., 153, 1189-1202, doi:10.1007/s10336012-0850-2, 2012.

Marengo, J. A., Borma, L. S., Rodriguez, D. A., Pinho, P., Soares, W. R., and Alves, L. M.: Recent Extremes of Drought and Flooding in Amazonia: Vulnerabilities and $\mathrm{Hu}-$ man Adaptation, American Journal of Climate Change, 2, 87-96, doi:10.4236/ajcc.2013.22009, 2013.

Jones, L. S. and Schumm, S. A.: Causes of Avulsion: An Overview, in: Fluvial Sedimentology VI, Blackwell Publishing Ltd., Oxford, UK, 169-178, 1999.

Junk, W.: Current state of knowledge regarding South America wetlands and their future under global climate change, Aquat. Sci., 75, 113-131, doi:10.1007/s00027-012-0253-8, 2013.

Junk, W. J., Bayley, P. B., and Sparks, R. E.: The flood pulse concept in river-floodplain systems, in: Proceedings of the International Large River Symposium, 14-21 September 1986, Toronto, Canada, edited by: Dodge, D. P., Canadian special publication of Fisheries and Aquatic Sciences, 106, 110-127, 1989.

Langstroth, R. P.: Biogeography of the Llanos de Moxos: natural and anthropogenic determinants, Geographica Helvetica, 66, 183-192, 2011

Latrubesse, E. M., Amsler, M. L., de Morais, R. P., and Aquino, S.: The geomorphologic response of a large pristine alluvial river to tremendous deforestation in the South American tropics:
The case of the Araguaia River, Geomorphology, 113, 239-252, doi:10.1016/j.geomorph.2009.03.014, 2009a.

Latrubesse, E. M., Baker, P. A., and Argollo, J.: Geomorphology of Natural Hazards and Human-induced Disasters in Bolivia, in: Developments in Earth Surface Processes, edited by: Edgardo, M. L., Elsevier, Philadelphia, USA, 181-194, 2009b.

Latrubesse, E. M., Stevaux, J. C., Cremon, E. H., May, J.-H., Tatumi, S. H., Hurtado, M. A., Bezada, M., and Argollo, J. B.: Late Quaternary megafans, fans and fluvio-aeolian interactions in the Bolivian Chaco, Tropical South America, Palaeogeogr. Palaeocl., 356-357, 75-88, 2012.

Lewin, J. and Ashworth, P. J.: The negative relief of large river floodplains, Earth-Sci. Rev., 129, 1-23, doi:10.1016/j.earscirev.2013.10.014, 2014.

Lombardo, U.: Neotectonics, flooding patterns and landscape evolution in southern Amazonia, Earth Surf. Dynam., 2, 493-511, doi:10.5194/esurf-2-493-2014, 2014.

Lombardo, U., Canal-Beeby, E., and Veit, H.: Eco-archaeological regions in the Bolivian Amazon: Linking pre-Columbian earthworks and environmental diversity, Geographica Helvetica, 66, 173-182, 2011.

Lombardo, U., May, J.-H., and Veit, H.: Mid- to late-Holocene fluvial activity behind pre-Columbian social complexity in the southwestern Amazon basin, The Holocene, 22, 1035-1045, doi:10.1177/0959683612437872, 2012.

Lombardo, U., Szabo, K., Capriles, J. M., May, J.-H., Amelung, W., Hutterer, R., Lehndorff, E., Plotzki, A., and Veit, H.: Early and Middle Holocene Hunter-Gatherer Occupations in Western Amazonia: The Hidden Shell Middens, PLoS ONE, 8, e72746, doi:10.1371/journal.pone.0072746, 2013.

Lombardo, U., Denier, S., and Veit, H.: Soil properties and preColumbian settlement patterns in the Monumental Mounds Region of the Llanos de Moxos, Bolivian Amazon, SOIL, 1, 65-81, doi:10.5194/soil-1-65-2015, 2015.

Martín-Vide, J. P., Amarilla, M., and Zárate, F. J.: Collapse of the Pilcomayo River, Geomorphology, 205, 155-163, doi:10.1016/j.geomorph.2012.12.007, 2014.

Mayle, F. E., Burbridge, R., and Killeen, T. J.: Millennial-scale dynamics of southern Amazonian rain forests, Science, 290, 22912294, doi:10.1126/science.290.5500.2291, 2000.

Mayle, F. E., Langstroth, R. P., Fisher, R. A., and Meir, P.: Longterm forest-savannah dynamics in the Bolivian Amazon: implications for conservation, Philos. T. Roy. Soc. B, 362, 291-307, doi:10.1098/rstb.2006.1987, 2007.

Mayorga, E., Logsdon, M. G., Ballester, M. V. R., and Richey, J. E.: Estimating cell-to-cell land surface drainage paths from digital channel networks, with an application to the Amazon basin, J. Hydrology, 315, 167-182, doi:10.1016/j.jhydrol.2005.03.023, 2005.

Melack, J. and Hess, L.: Remote Sensing of the Distribution and Extent of Wetlands in the Amazon Basin, in: Amazonian Floodplain Forests, edited by: Junk, W. J., Piedade, M. T. F., Wittmann, F., Schöngart, J., and Parolin, P., Ecological Studies, Springer Netherlands, 43-59, 2011.

Micheli, E. R., Kirchner, J. W., and Larsen, E. W.: Quantifying the effect of riparian forest versus agricultural vegetation on river meander migration rates, central Sacramento River, California, USA, River Res. Appl., 20, 537-548, doi:10.1002/rra.756, 2004. 
Nelson, B. W., Kapos, V., Adams, J. B., Wilson, J. O., and Braun, O. P. G.: Forest Disturbance by Large Blowdowns in the Brazilian Amazon, Ecology, 75, 853-858, doi:10.2307/1941742, 1994.

Nichols, G. and Fisher, J.: Processes, facies and architecture of fluvial distributary system deposits, Sediment. Geol., 195, 75-90, doi:10.1016/j.sedgeo.2006.07.004, 2007.

Pärssinen, M. H., Salo, J. S., and Räsänen, M. E.: River floodplain relocations and the abandonment of Aborigine settlements in the Upper Amazon Basin: A historical case study of San Miguel de Cunibos at the Middle Ucayali River, Geoarchaeology, 11, 345-359, doi:10.1002/(sici)15206548(199607)11:4<345::aid-gea3>3.0.co;2-1, 1996.

Peixoto, J. M. A., Nelson, B. W., and Wittmann, F.: Spatial and temporal dynamics of river channel migration and vegetation in central Amazonian white-water floodplains by remotesensing techniques, Remote Sens. Environ., 113, 2258-2266, doi:10.1016/j.rse.2009.06.015, 2009.

Plotzki, A., May, J. H., and Veit, H.: Past and recent fluvial dynamics in the Beni lowlands, NE Bolivia, Geographica Helvetica, 66, 164-172, 2011.

Plotzki, A., May, J. H., Preusser, F., Roesti, B., Denier, S., Lombardo, U., and Veit, H.: Geomorphology and evolution of the late Pleistocene to Holocene fluvial system in the south-eastern Llanos de Moxos, Bolivian Amazon, Catena, 127, 102-115, doi:10.1016/j.catena.2014.12.019, 2015.

Pouilly, M., Beck, S. G., Moraes, R. M., and Ibanez, C.: Diversidad biologica en la llanura de inundacion del Rio Mamore : importancia ecologica de la dinamica fluvial, Centro de Ecologia Simon I. Patino, Santa Cruz, 383 pp., 2004.

Prümers, H. and Jaimes Betancourt, C.: 100 años de investigación arqueológica en los Llanos de Mojos, Arqueoantropológicas, 4, 11-53, 2014.

Salo, J., Kalliola, R., Hakkinen, I., Makinen, Y., Niemela, P., Puhakka, M., and Coley, P. D.: River dynamics and the diversity of Amazon lowland forest, Nature, 322, 254-258, 1986.

Schöngart, J. and Junk, W. J.: Forecasting the flood-pulse in Central Amazonia by ENSO-indices, J. Hydrol., 335, 124-132, doi:10.1016/j.jhydrol.2006.11.005, 2007.

Slingerland, R. and Smith, N. D.: Necessary conditions for a meandering-river avulsion, Geology, 26, 435-438, doi:10.1130/0091-7613(1998)026<0435:ncfamr>2.3.co;2, 1998.

Slingerland, R. and Smith, N. D.: River Avulsions and their deposits, Annu. Rev. Earth Pl. Sc., 32, 257-285, doi:10.1146/annurev.earth.32.101802.120201, 2004.
Smith, N. D., Cross, T. A., Dufficy, J. P., and Clough, S. R.: Anatomy of an avulsion, Sedimentology, 36, 1-23, doi:10.1111/j.1365-3091.1989.tb00817.x, 1989.

Stouthamer, E. and Berendsen, H. J. A.: Avulsion: The relative roles of autogenic and allogenic processes, Sediment. Geol., 198, 309325, doi:10.1016/j.sedgeo.2007.01.017, 2007.

Thomas, E.: New light on the floristic composition and diversity of indigenous territory and national park Isiboro-Sécure, Bolivia, Biodivers. Conserv., 18, 1847-1878, doi:10.1007/s10531-0089561-7, 2009.

Thompson, S. E., Sivapalan, M., Harman, C. J., Srinivasan, V., Hipsey, M. R., Reed, P., Montanari, A., and Blöschl, G.: Developing predictive insight into changing water systems: use-inspired hydrologic science for the Anthropocene, Hydrol. Earth Syst. Sci., 17, 5013-5039, doi:10.5194/hess-17-50132013, 2013.

Wallace, R., Martinez, J., Lopez-Strauss, H., Barreta, J., Reinaga, A., and Lopez, L.: Conservation Challenges Facing Two Threatened Endemic Titi Monkeys in a Naturally Fragmented Bolivian Forest, in: Primates in Fragments, edited by: Marsh, L. K. and Chapman, C. A., Developments in Primatology: Progress and Prospects, Springer New York, 493-501, 2013.

Weissmann, G., Hartley, A., Scuderi, L., Nichols, G., Davidson, S., Owen, A., Atchley, S., Bhattacharya, J., Chakraborty, T., and Ghosh, P.: Prograding distributive fluvial systems: geomorphic models and ancient examples, New Frontiers in Paleopedology and Terrestrial Paleoclimatology: SEPM, Special Publication 104, 131-147, 2013.

Whitney, B. S., Mayle, F. E., Punyasena, S. W., Fitzpatrick, K. A., Burn, M. J., Guillen, R., Chavez, E., Mann, D., Pennington, R. T., and Metcalfe, S. E.: A 45 kyr palaeoclimate record from the lowland interior of tropical South America, Palaeogeogr. Palaeocl., 307, 177-192, doi:10.1016/j.palaeo.2011.05.012, 2011.

Wittmann, H., von Blanckenburg, F., Guyot, J. L., Maurice, L., and Kubik, P. W.: From source to sink: Preserving the cosmogenic 10Be-derived denudation rate signal of the Bolivian Andes in sediment of the Beni and Mamoré foreland basins, Earth Planet. Sc. Lett., 288, 463-474, doi:10.1016/j.epsl.2009.10.008, 2009.

Wolter, K. and Timlin, M. S.: El Niño/Southern Oscillation behaviour since 1871 as diagnosed in an extended multivariate ENSO index (MEI.ext), Int. J. Climatol., 31, 1074-1087, doi:10.1002/joc.2336, 2011. 